\title{
商業活動の立地均衡と社会的効率性* \\ SPATIAL EQUILIBRIA OF RETAIL ACTIVITY AND THEIR SOCIAL EFFICIENCY
}

文 世一**

By Se-il MUN

\section{1. はじめに}

本研究の目的は、都市内における商業活動の空間 分布が、市場メカニズムによっていかに決定される かを分析し、そのような空間分布が、資源配分上、 望ましいものであるかどうか、また望ましくない場 合には、いかなる政策が求められるかを明らかにす ることである。

商業立地の問題に関しては、消費者の買い物行動 の分析 ${ }^{1)}$ 、商業立地分布の予測モデル2)、あるいは特 定の目的関数を最大化する計画モデル3)などに関す る研究が従来より行われてきた。これらの研究は、 都市計画への応用を指向するものが多いが、一方、 経済学では、Hotelling以来、空間的競争に関する理 論的研究が数多く行われている ${ }^{4)}$ 。そこでは、少数

（多くは二つ）の企業が、空間上（多くは一次元の 直線あるいは円周上）で、立地選択や価格付けを通 して集客競争を行った結果実現する均衡解を分析し ている。総合的なアプローチとしては、Roy and Johansson(1984) 5) らが、消費者、小売業者、デべ ロッバーらの行動を定式化し、それらの相互依存関 係を考慮したモデルを提案している。しかし、分析 の枠組みを提案するにとどまっており、そのような モデルによって求められる商業立地分布がいかなる ものとなるかに関して具体的分析は行われていない。 同様の問題意識のもとに、文・小林・吉川 $(1989)^{6)}$ は、消費者、小売企業、および計画者の間の相互関 係を明示的にモデル化し、それを地域内の一地区に おける商業地再開発の計画代替案の分析に適用した。 ところで、実際の都市では、大規模店舗と小規模

*キーワーズ : 産業立地, 土地利用, 都市計画 ** 正会員 工博 東北大学助教授 大学院情報科学研究科 （テ980-77 仙台市青葉区片平2-1-1 FAX: 022-263-9858)
店舗という異なった企業組織の形態が存在する。こ のような企業組織のあり方の違いは立地分布や資源 配分に影響を与えるはずであるが、そのような問題 に関する研究はほとんど見られない。

本研究では、文・小林・吉川(1989)を拡張し、複 数の商業地間での立地配分の問題を主たる分析の対 象とする。その際、特に企業組織の違いを明示的に 考慮するため、二通りの立地均衡をモデル化する。 一つはすべての小売業が小規模な企業であり、それ ぞれは完全競争的に行動する。これをモデル 1 と呼 ぶ。もう一つは、各地区にただ一つの大規模店舗が 立地し、それぞれが寡占競争的に、店舗の規模を決 めると仮定する。これをモデル 2 と呼ぶ。さらに本 研究では、パレート効率的な立地配分を求める計画 問題を定式化する。そしてこの問題の解と、上の二 通りの立地均衡解とを比較し、それらの社会的効率 性を評価することとする。さらに、数值シミュレー ションにより、立地分布の特性と、経済的厚生の分 配について分析を行う。

\section{2. 基本モデル（モデル 1 )}

\section{（1）仮定}

地域内には、I個の居住地と、J個の商業地がある ものとする。各居住地の消費者数は外生的に与えら れる。各商業地では、デベロッパーが地主から借り た土地に資本を投入して商業施設を建設し、それを 小売業者に貸す。小売業者は一定の床面積を使用す るとともに、労働者を雇用して商業活動を行う。

\section{（2）消費者の行動}

各消費者は、地域内で一定量の財を購入すると仮 定する。すなわち消費財に対する需要は非弾力的で 
ある。消費者が財を購入する際には、それを直接見 たり他と比較するため、自ら商店まで出かける必要 がある。その際、消費者にとっては、最適な品物を 探しあてるため、より品ぞろえの多い店で買う方が 好ましい。また、そのような買い物には、交通費用 を要する。上述のように、財に対する需要は非弹力 的なので、消費者の効用は品ぞろえと交通費用にの み依存する。そこで、地区iに居住する消費者が商業 地 $\mathrm{j} て ゙$ 買い物を行った場合の効用を次のように特定化 する。

$$
V_{i j}=\alpha \ln W_{j}-\gamma d_{i j}+\varepsilon_{i j}
$$

ここに $W_{j}$ は商業地 $\mathrm{j} の$ 規模であり、従業者数で定義さ

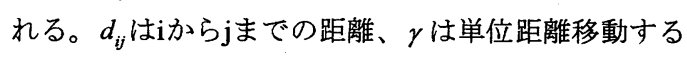
ための金銭的及び時間費用である。さらに $\varepsilon_{i j}$ は、確 率的に変動する項である。上式右辺の第 1 項は、品 ぞろえが豊富であることによる便益（たとえば探索 費用の節約など）を表しており、商業地規模の大き さを品ぞろえの代理指標としている。上式のような 定式化は、これまでもしばしば採用されているが、 本論文の後の節で示すように、この項の存在が外部 効果を発生させ、資源配分に影響を与える点に着目 した研究は行われていない。第 2 項は消費者の居住 地から商業地までの交通費用を表している。第 3 項 は消費者ごとの嗜好の違いを表す項であり、その解 釈については、Anderson, et.al.(1992)において詳しく 述べられている7)。いま $\varepsilon_{i j}$ が、それぞれ独立に同一 のワイブル分布に従うと仮定すると、地区 $\mathbf{i}$ の消費者 が商業地 $\mathrm{j}$ 選択する確率が、次のようなロジットモ デルにより表わされる。

$$
P_{i j}=\frac{\exp \mu\left(\alpha \ln W_{j}-\gamma d_{i j}\right)}{\sum_{k} \exp \mu\left(\alpha \ln W_{k}-\gamma d_{i k}\right)}
$$

ここに $\mu$ は、確率項の分散の大きさを表すパラメー

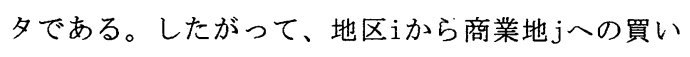
物トリップ数 $S_{i j}$ 、および商業地jへの吸引トリップ数 $D_{j}$ は、次の式によって求められる。

$$
\begin{aligned}
& S_{i j}=N_{i} P_{i j} \\
& D_{j}=\sum_{i} S_{i j}
\end{aligned}
$$

ただし $N_{i}$ は、地区iにおける消費者数を表わす。

\section{（3）小売企業の行動}

地域内に立地する小売業は、すべて小規模であり、
同一の規模を持つと仮定する。ここでは、一般性を 失わないので、小売業の規模を 1 と仮定する。各小 売業の利潤は次のように定義される。

$$
\pi_{j}^{I}=\frac{e D_{j}}{W_{j}}-w-u r_{j}
$$

ここにeは、買い物客一人について得られる粗利益 （=消費者一人当たりの購入額一財の仕入れ費用） である。前項で仮定したように、消費財の需要は非 弹力的なので、eは定数である。 $D_{j}$ は、商業地全体 での買い物客数なので、上式右辺の第 1 項は一企業 あたりの粗利益である。第 2 項の $w$ は、従業員一人 あたりの賃金、第 3 項の $\boldsymbol{u}$ は従業員一人あたりの床 面積、そして $r_{j}$ は単位床面積当たりの賃貸料である。 ここでuは、すべての商業地において一定值である と仮定される。各小売業者は、(5)式で定義される利 潤が最大となる場所に立地する。その際、各小売業 は、自らの立地が消費者の行動に及ぼす影響を無視 できるほど小さいと考えるので、買い物客数は与え られたものとして立地選択を行う。

\section{（4）デベロッパーの行動}

デベロッパーは、土地と資本を投入して商業施設 を建設する。建設技術は規模に関して収穫一定であ ると仮定する。デベロッパーは多数いるものと想定 するが、上述の仮定より一次同次の生産関数を持つ ので、各地区は一人のデベロッパーによって開発さ れるかのように定式化することができる。そこで、 本研究では、生産関数を次のように特定化する。

$$
F_{j}=K_{j}^{\tau} L_{j}^{1-\tau}
$$

ここに $F_{j}$ は、地区jにおける商業床の面積、 $K_{j} 、 L_{j}$ はそれぞれ資本及び土地の投入量である。 メータであり、 $0<\tau<1 の$ 範囲にある。このときデべ ロッパーの利潤は次の式により表される。

$$
\phi_{j}=r_{j} F_{j}-c K_{j}-\rho_{j} L_{j}
$$

ここにcおよび $\rho_{j}$ は、それぞれ、資本の価格及び土 地の地代である。利潤最大化の一階の条件より、次 の関係が成り立つ。

$$
\frac{K_{j}}{L_{j}}=\frac{\tau}{1-\tau} \cdot \frac{\rho_{j}}{c}
$$

\section{（5）地主の行動}

地主は、商業地における市場地代 $\rho_{j}$ が、土地の機 
会費用 $b$ を上回る場合は、所有する土地を商業用途 のために供給し、下回る場合は供給しない。

\section{（6）市場均衡}

ここでは、完全競争が行われ、経済活動への参入、 退出は自由であると仮定する。このような仮定は非 現実的であることはいうまでもないが、本研究の一 つの目的である、代替的な資源配分方式の比較を行 うため、一つの参照点としてこれを求めておくこと は無意味ではないと考える。このモデルにおける市 場均衡は、消費者の買い物流動、小売業の立地均衡、 商業床市場の均衡、そして土地市場の均衡によって 表される。なお、ここでは労働市場と資本市場はモ デル化されていないので、賃金 $w$ と資本価格 $c$ は外 生的に与えられる。

以下、それぞれの均衡条件について述べる。

(a) 消費者の買い物流動は(3)(4)式によって表わされ る。

(b) 小売業は、正の利潤が得られる商業地があれば、 そこに参入する。したがって均衡においては、利潤 はゼロとなる。一方、利潤が負となるような商業地 には立地しない。これを定式化すると次の通り。

$$
\begin{array}{ll}
\frac{e D_{j}}{W_{j}}-w-u r_{j}=0, & \text { if } W_{j}>0 \\
\frac{e D_{j}}{W_{j}}-w-u r_{j} \leq 0, & \text { if } W_{j}=0
\end{array}
$$

（c）床市場においては、商業床の需要が供給量を超過 しない。このことは、次のように定式化される。

$$
u W_{j} \leq F_{j}
$$

また、潜在的に参入しようとするデベロッパーは多 数存在するので、地区jにおいて商業床の建設が行わ れるのなら、デベロッパーの利潤はゼロになる。 すなわち

$$
\begin{array}{ll}
\phi_{j}=0, & \text { if } F_{j}>0 \\
\phi_{j} \leq 0, & \text { if } F_{j}=0
\end{array}
$$

（d）各地区において、商業活動の立地できる土地面積 の上限は、都市計画の制約などにより、固定されて いると仮定する。このことと、（5）で述べた地主 の行動を考慮すると、土地市場の均衡は次のように 表わされる。

$$
\begin{array}{ll}
\text { if } \rho_{j}>b, & L_{j}=\overline{L_{j}} \\
\text { if } \rho_{j}=b, & 0 \leq L_{j} \leq \overline{L_{j}}
\end{array}
$$

$$
\text { if } \rho_{j}<b, \quad L_{j}=0
$$

ここに $\bar{L}_{j}$ は、外生的に与えられる商業地面積の上限 である。

本モデルの、内生変数は、 $S_{i j}, D_{j}, W_{j}, K_{j}, L_{j}, r_{j}$, $\rho_{j}$ で、合計 $I \times J+6 J$ である。これに対し、均衡条件 式が、(3),(4),(8),(9),(10),(11),(12)の $I \times J+6 J$ 本なの で均衡解を求めることができる。

\section{3. 大規模小売店の立地均衡（モデル 2）}

ここでは、各地区に一つの大規模小売り店があり、 寡占的競争を行う状況を想定する。したがって各商 業地の規模は、そこに一つだけ立地する小売り店の 規模に等しい。各小売り店は、他の地区に立地する 店舗の規模や消費者の反応を考慮しながら、戦略的 に店舗の規模を選択するという点が、前節のモデル と異なっている。 小売業者の利潤は次の式により定義される。

$$
\pi_{j}^{I I}=e D_{j}-w W_{j}-u r_{j} W_{j}
$$

各小売り店が規模に関して利潤を最大化する条件は

$$
\begin{aligned}
& e \frac{\partial D_{j}}{\partial W_{j}}-w-u r_{j}=0, \quad \text { if } W_{j}>0 \\
& e \frac{\partial D_{j}}{\partial W_{j}}-w-u r_{j} \leq 0, \quad \text { if } W_{j}=0 \\
& こ こ に \frac{\partial D_{j}}{\partial W_{j}}=\mu \alpha\left\{\frac{D_{j}}{W_{j}}-\sum_{i} \frac{N_{i} P_{i j}^{2}}{W_{j}}\right\}
\end{aligned}
$$

さらに、各小売業の利潤は、潜在的な参入可能性の ためゼロになる。もし正の利潤を得ている小売業が あれば、潜在的な参入者は、より高い貨料を提示し て既存の企業と置き換わろうとするからである。消 費者、デベロッパー、及び地主の行動に関するモデ ルは前節と同様である。したがって、モデル 1 の市 場均衡条件式の内、(9)式を(14)式で置き換えること により、モデル 2 の市場均衡解が求められる。

\section{4. 立地均衡の社会的効率性}

本節では、まずパレート効率的な立地配分問題を 定式化する。そしてその問題の最適条件と、立地均 衡の条件を比較することにより、上述した二通りの 立地均衡の社会的効率性を評価することとする。 


\section{（1）パレート効率的な立地配分}

パレート効率的な資源配分は、社会的余剰を最大 化することによって達成される。社会的余剩(SS)は、 消費者余剩 $(\mathrm{CS})$ 、小売業の利潤 $(\mathrm{RP}) 、$ デベロッパー の利潤(DP)、そして地主の地代収入から土地の機会 費用を除いたもの(LR)の和として定義される。すな わち最大化すべき目的関数は次のように書ける。

$$
S S=C S+R P+D P+L R
$$
ここに

$$
\begin{aligned}
& C S=\frac{1}{\mu} \sum_{i} N_{i} \log \left[\sum_{j} \exp \left\{\mu\left(\alpha \ln W_{j}-\gamma d_{i j}\right)\right\}\right] \\
& R P=\sum_{j}\left(e D_{j}-w W_{j}-u r_{j} W_{j}\right) \\
& D P=\sum_{j}\left(r_{j} K_{j}^{\tau} L_{j}^{1-\tau}-c K_{j}-\rho_{j} L_{j}\right) \\
& L R=\sum_{j}\left(\rho_{j}-b\right) L_{j}
\end{aligned}
$$

この問題の制約条件は次の通り。

$$
\begin{aligned}
& \sum_{j} S_{i j}=N_{i} \\
& \sum_{i} S_{i j}=D_{j} \\
& u W_{j} \leq K_{j}^{\tau} L_{j}^{1-\tau} \\
& L_{j} \leq \overline{L_{j}}
\end{aligned}
$$

および $S_{i j} \geq 0, W_{j} \geq 0, D_{j} \geq 0, K_{j} \geq 0, L_{j} \geq 0$ 。ここで 消費者余剰CSは、(1)式によって表されるランダム効 用の最大值の期待值を、居住地ごとの消費者につい て集計したものである ${ }^{8)}$

\section{（2）立地均衡の社会的効率性}

Lagrange乗数法により、上記の問題の最適条件を 求める。詳細は省略するが、 $K_{j}, L_{j}$ に関する最適条 件を整理することによって、それぞれ (8)、(12)と同 様の式が得られる。その際、(23)式および(24)式に関 するLagrange乗数を、それぞれ、商業床の家賃およ び商業地の地代と解䣋している。この結果から、商 業床市場、土地市場については、市場機構が効率的 な資源配分を達成することがわかる。ところが、 $W_{j}$ に関する最適条件を整理すると次の式が得られる。

$$
\begin{aligned}
\alpha \frac{D_{j}}{W_{j}}+e \frac{D_{j}}{W_{j}}-W_{j}\left(e \frac{D_{j}}{W_{j}^{2}}\right)-w-u r_{j}=0 \\
\text { if } W_{j}>0 \\
\alpha \frac{D_{j}}{W_{j}}+e \frac{D_{j}}{W_{j}}-W_{j}\left(e \frac{D_{j}}{W_{j}^{2}}\right)-w-u r_{j} \leq 0 \\
\text { if } W_{j}=0
\end{aligned}
$$

上式は、これに対応するモデル 1 の(9)式、あるいは
モデル 2 の(14)式のいずれとも異なっている。この ことは、小売業者の自由な立地行動の結果実現する 市場均衡が、パレート効率性を達成しないというこ とを意味する。

(25)式を、モデル 1 の(9)式と比較すると、左辺第 1 項と第 3 項が加わっている点が異なっている。

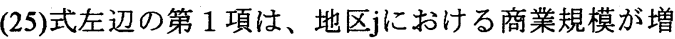
加することによる消費者余剩の変化である。これは、 品ぞろえが豊富になることによって消費者が得る便 益といえる。第 3 項は、 $e D_{j} / W_{j}$ における分母の $W_{j}$ が 増えることによる変化なので、これは商店の立地が 増えることによって、既存の小売業の単位当たり売 上が減少する効果である。これらはいずれも外部効 果であり、小売業は個々の利潤最大化行動において これらの効果を考慮しない。モデル 1 の設定のもと で、効率的な資源配分を、市場メカニズムにより分 権的に達成するためには、小売業者に税を課すか補 助金を支給する必要があるが、その額は次式により 計算される。

$$
\delta_{j}^{I}=(\alpha-e) \frac{D_{j}}{W_{j}}
$$

一方、モデル 2 の(14)式における第 1 項は、小売 業の限界収入に相当するものである。この場合は、 上記の外部効果に加え、寡占による不完全競争のた め, 資源配分が非効率となる。この場合の税／補助 金は次式のようになる。

$$
\delta_{j}^{I I}=\alpha \frac{D_{j}}{W_{j}}-e \mu \alpha\left\{\frac{D_{j}}{W_{j}}-\sum_{i} \frac{N_{i} P_{i j}^{2}}{W_{j}}\right\}
$$

(26), (27)式に示した $\delta_{j}^{I} 、 \delta_{j}^{I I}$ の值が正なら補助金、負 なら課税となる。これらの正負はパラメータ $\alpha 、 e 、$ $\mu$ の相対的大きさに依存する。具体的な場合分けに ついては後述する。

(9),(14),(25)式を用いて、モデルごとの小売業立地 量の大きさを比較することができる。図一 1 におけ る右上がりり曲線は、三式に共通に含まれる $w+u r_{j}$ である。三式におけるそれ以外の部分は、図の右下 がりの曲線によって表される。モデル 1 、モデル $2 、$ そしてパレート効率的配分による小売業立地量は、 それぞれ、図における $W_{j}^{I} 、 W_{j}^{I I} 、 W_{j}^{O}$ のように求めら れる。これら三本の曲線の位置関係は、やはりパラ メータ $\alpha 、 e 、 \mu$ の相対的大きさに依存するので、 図一 1 は一つの特殊ケースに過ぎない。 


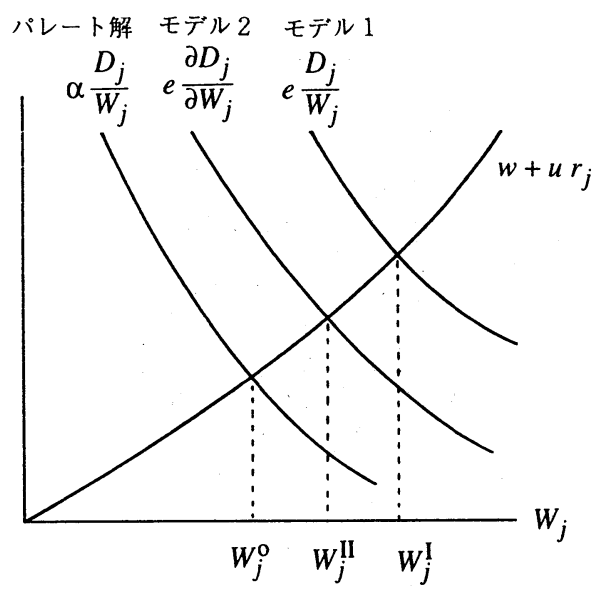

図ー1 ゾーン別商業規模の決定方法

ここでは、既存の推定事例 6)を考慮して、 $0<\mu \alpha<1$ の場合を想定する。このとき、(9)式と(14) 式の第 1 項を比較すれば、明らかに

$$
\frac{\partial D_{j}}{\partial W_{j}}<\frac{D_{j}}{W_{j}}
$$

なので、 $W_{j}^{I I}<W_{j}^{I}$ は常に成り立つ。すなわち宾占状 態における小売業立地量は、完全競争の場合よりも 必ず少なくなる。以上の想定のもとでは、 $\alpha$ との相 対的大きさにより、次の三つのケースが生ずる可能 性がある。

[Case A] $\alpha<e$ であり、かつ $\alpha$ が $e$ に比べ相当小さな

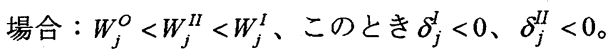

[Case B] 同じく $\alpha<e$ であるが、Case Aの場合ほど $\alpha$ が小さくない場合 : $W_{j}^{I I}<W_{j}^{O}<W_{j}^{I} 、 \delta_{j}^{I}<0 、 \delta_{j}^{I I}>0$ 。 [Case C] $\alpha>e$ の場合: $W_{j}^{I I}<W_{j}^{I}<W_{j}^{O}, \delta_{j}^{I}>0$ 、 $\delta_{j}^{I I}>0$ 。

なお、上述の推定事例6) と、入手可能な統計資料に よる大雑把な試算によると、 $\alpha$ は $e$ に比べて相当低い 值となることがわかった。したがって現実にはCase Aが実現している可能性が高いものと思われる。 図一 1 も実はこのケースについて描いたものである。 このケースでは、モデル 1、モデル2のいずれの立 地均衡解もパレート解に比べて過大となっている。 特に寡占競争的なモデル 2 よりも、完全競争的なモ デル 1 の方が、パレート解とのかい離が大きいとい う結果は、意外とも思われる。これは、モデル 2 の 場合, 臭占による不完全競争の影響と外部効果が互 いに打ち消しあう方に作用したためである。

\section{5. 商業活動の空間分布と経済厚生の分配}

本節では、モデルに具体的パラメータを与えて数 值シミュレーションを行い、企業組織の違いやパラ メータの変化が立地分布と資源配分に及ぼす影響に ついて分析する。

ここで対象とする都市は、図ー2に示すように、 一直線上に並んだ 9 個の地区からなるものとする。 これらすべての地区に商業活動が立地することがで き、消費者世帯も居住している。すなわち $I=J=9$ である。

シミュレーションにおける、基本ケースのパラ メータ值、及び外生変数值は次の通りである。

$$
\alpha=0.8, \quad \gamma=0.6, \quad e=10.0, \quad w=10.0,
$$$$
u=40, \quad c=1.0, \quad \tau=0.6, \quad b=0
$$$$
N_{j}=50000, \quad \bar{L}_{j}=50000, \quad j=1,2, \ldots, 9
$$

\begin{tabular}{|l|l|l|l|l|l|l|l|l|}
\hline 1 & 2 & 3 & 4 & 5 & 6 & 7 & 8 & 9 \\
\hline
\end{tabular}

\section{図一2 数値分析における都市}

\section{（1）商業活動の空間分布}

図一3には、上述の設定のもとでシミュレーショ ンを実行し、地区別立地分布を求めた結果を示して いる。このモデルでは、図ー3(1)に示すような単峰 型（パターンS）と、図ー3 (2)のような多峰型（パ ターンM）という二通りの分布パターンが出現する。 図は、モデル 1 による計算結果を示しているが、モ デル 2、パレート効率配分においても同様のパター ンが生じる。この二通りの分布パターンの形成に決 定的な影響を与えるパラメータは、 $\alpha$ とである。そ こでこれら二つのパラメータの值と分布パターンの 関連について調べ、それを図一4のようにまとめて 示した。図には、右下がりの曲線が 2 本描かれてい る。上方の曲線は、モデル 2 において二つの分布バ ターンを分けるパラメータの境界值を連㸚たもので あり、下方はモデル 1 及びパレート解に対するもの である。図によると、 $\alpha$ 大゙大き $\gamma$ が大きいほど、多 


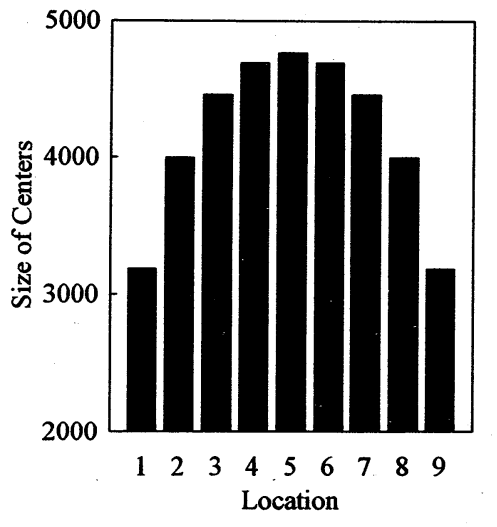

（1）単峰型立地分布（パターンS）

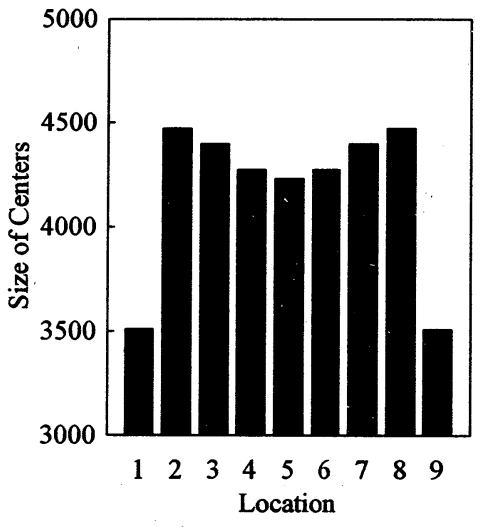

（2）多峰型立地分布 (パターンM)

图一3立地分布のパターン

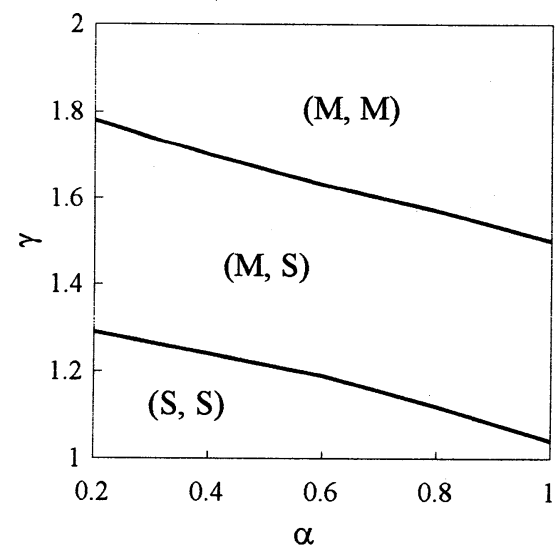

$(\mathrm{S}, \mathrm{S}) ： \begin{aligned} & \text { すべてのモデルにおいてパターンSの } \\ & \text { 立地分布 }\end{aligned}$

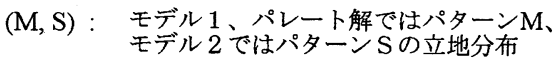

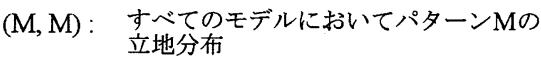

図一4 パラメータと立地パターン

峰型（パターンM）の立地分布になりやすいことが わかる。また、モデル 1 及びパレート解の方が、モ デル 2 に比べて、多峰型の立地分布になるパラメー タの範囲が大きい。

\section{（2）主体別経済厚生の分配}

モデル 1、モデル 2、パレート効率的立地配分と いう、3 通りの資源配分方式の間での、各主体別経 済的厚生の大小関係は、表一 1 のような 5 通りの
ケースに分けられることがわかった。これは、4．

（2）において行われた、地区別立地量に関する ケース分けと、ほぼ対応している。ただしCase B1, B2及びCase C1，C2は、それぞれCase B及びCの中で のさらなる場合分けである。図一 5 には、それぞれ のケースが実現するパラメータの範囲が示されてい る。前節でも述べたように、実際には、Case Aの実 現している可能性が高いので、以下ではこのケース についてのみ詳しく説明することとする。本節の冒 頭で示した基本ケースのパラメータも、このケース に該当する。

図一 6 には、3 通りの資源配分方式別に、全体的 な経済厚生と、その主体別分配の状況を図示してい る。ここで小売企業とデベロッパーについては利潤 が常にゼロなので、図には表われない。この図では、 モデル 2 の設定のもとでの社会的余剩の值がモデル 1 のもとでの值よりも大きい。すなわち大規模店舗 による寊占状態の方が小規模店舗間の完全競争より も、社会全体としては効率的である。しかし、消費 者余剰はモデル 1 、モデル 2 、パレート効率配分の 順に高いので、社会的効率性向上と消費者の厚生改 善はトレード・オフの関係にある。図によると、モ デル 1 と 2 の間では、社会的効率性の改善が主とし て地主の地代収入の増加によって達成されている。 一方、パレート効率的配分では、モデル 1 やモデル 2 にはない政府の収入が、社会的余剩の大きな割合 を占めている。これは4（2）において述べたよう に、Case Aのもとでパレート効率的配分を分権的に 


\section{表一 1 主体別経済厚生に関する場合分け}

\begin{tabular}{|c|c|c|c|}
\hline & 消費者余剩 & 総地代収入 & 社会的余剩 \\
\hline Case A & $C S^{O}<C S^{I I}<C S^{I}$ & $T R^{O}<T R^{I}<T R^{I I}$ & $S S^{I}<S S^{I I}$ \\
\hline Case B1 & $C S^{I I}<C S^{O}<C S^{I}$ & $T R^{O}<T R^{I}<T R^{I I}$ & $S S^{I}<S S^{I I}$ \\
\hline Case B2 & $C S^{I I}<C S^{O}<C S^{I}$ & $T R^{O}<T R^{I}<T R^{I I}$ & $S S^{I I}<S S^{I}$ \\
\hline Case C1 & $C S^{I I}<C S^{I}<C S^{O}$ & $T R^{I}<T R^{O}<T R^{I I}$ & $S S^{I I}<S S^{I}$ \\
\hline Case C2 & $C S^{I I}<C S^{I}<C S^{O}$ & $T R^{I}<T R^{I I}<T R^{O}$ & $S S^{I I}<S S^{I}$ \\
\hline
\end{tabular}

ここに

$S S^{I}, S S^{I I}$ は、それぞれ、モデル 1、モデル 2 の設定のもとでの社会的余剩

$C S^{I}, C S^{I I}, C S^{O}$ は、それぞれ、モデル 1 、モデル 2 、パレート効率的立地配分のもとでの消費者余剩

$T R^{I}, T R^{I I}, T R^{O}$ は、それぞれ、モデル 1 、モデル 2 、パレート効率的立地配分のもとでの総地代

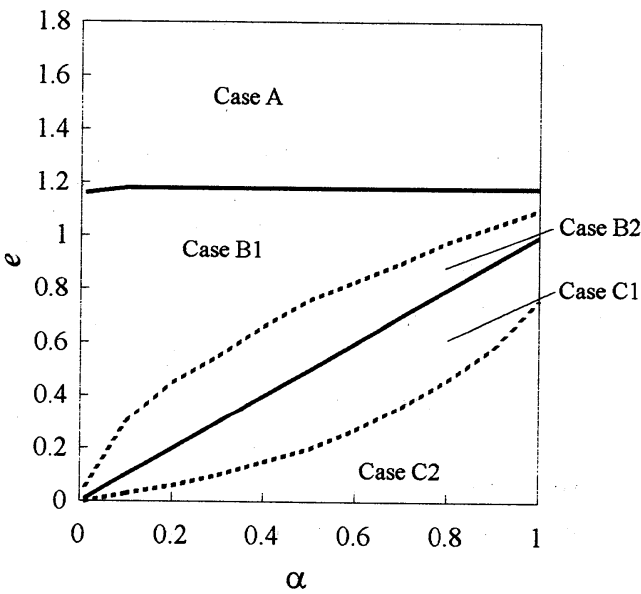

図一5 各ケースの生じるパラメータ範囲

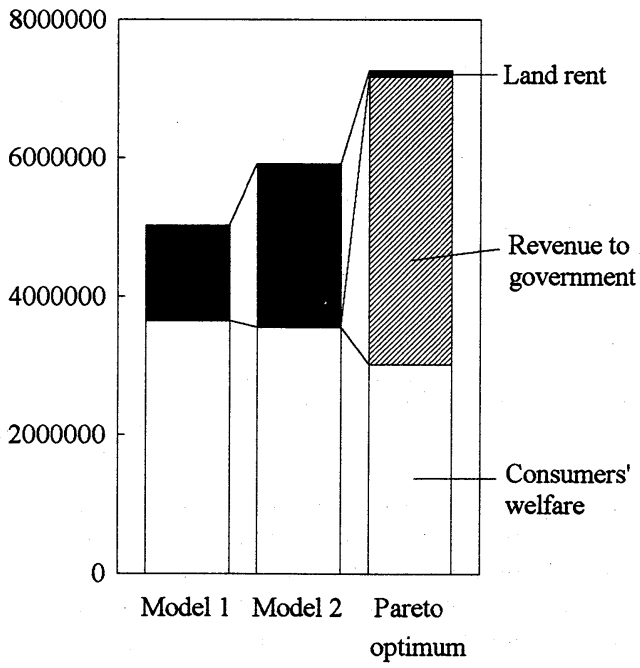

図-6 主体別経済厚生の分配
達成するには、各小売業者から立地税を徵収する必 要があるためである。この政府の収入を適切に分配 することによって、政策の実施による一部の主体の 厚生損失を補償しても、他の主体の経済厚生を向上 させることができる。

\section{6. おわりに}

本稿では、二通りの商業立地均衡をモデル化し、 空間的分布の性質、およびそれらの社会的効率性に ついて検討した。

小売業の立地行動は、消費者や他の小売業に外部 効果を及ぼすとともに、大規模店舗の場合は不完全 競争により、効率的な資源配分を達成することがで きない。これら複数の要因が重なり合うので、場合 によっては、各企業が完全競争的に行動する場合が、 寡占の場合よりも非効率になることもありうる。ま た、商業立地の分布パターンや経済厚生の大小関係 は一様ではなく、パラメータ值の相対的大きさに依 存して、いくつかのケースが可能であることがわ かった。本稿では、限られた実証分析の事例にもと づいて、実現する可能性の高いケースを示したが、 それがどのような状況においても成り立つかは確か ではない。様々な都市や地域における実証分析の知 見を積み重ねる必要がある。実証分析は、上で明ら かにされた外部効果や経済厚生の差異が、量的にど れほど重要かについて明らかにするためにも必要で ある。その他に残された課題としては、次のものが 考えられる。 
（1）本研究では、小規模な小売業者の立地均衡と、 大規模小壳業者の立地均衡を個別に分析したが、実 際には、これら二種類の企業組織が各商業地区で共 存している場合が一般的である。これら二つのタイ プの小売業者間の競争や補完的関係などをモデル化 することによって、より現実的な分析が行えるもの と思われる。

（2）このモデルを用いて、都市計画的手段が、立 地分布や経済厚生に及ぼす影響を分析することが応 用研究の課題として残されている。たとえばゾーニ ングのような土地利用規制の効果は、(12)式におけ る右辺の $\overline{L_{j}}$ を、また、交通施設整備は、(1)式におけ る地区間距離 $d_{i j}$ を操作することによって分析できる。 さらには、分析目的に応じて、モデルに制度上の制 約条件を追加するなどの修正が必要であろう。

謝辞 : 本研究の実施にあたって、京都大学大学院の 松村憲一氏（現在日本総合研究所）には計算作業等 でご協力いただいた。また現在は関西大学の吉川和 広教授、広島大学の奥村誠助教授、そして京都大学 の秀島栄三助手には、研究の各段階において様々な コメントやご助力を賜った。さらに本論文の旧稿に 対し、神戸大学の富田安夫講師および匿名の査読者 から有益なご意見をいただき、それらは論文の改善 に大きく役立った。なお、本稿は文部省科学研究費
（奨励研究A、課題番号06750556）の補助を受けて 行った研究成果を含んでいる。ここに記して感謝の 意を表したい。

\section{参考文献}

1) 中西正雄 : 小売吸引力の理論と測定, 千倉書房, 1983.

2) Miller, E. J. and Lerman, S. R. : A model of retail location, scale and intensity, Environment and Planning A, Vol.11, pp.177-192, 1979

3) Wilson, A. G., Coelho, J. D., Macgill, S. M. and Williams, H. C. W. L. : Optimization in Location and Transport Analysis, John Willey, chichester, U.K., 1981.

4) Gabszebicz, J. J. and Thisse, J. -F. : Spatial competition and the location of firms, in Location Theory, Chur, Switzerland: Harwood Academic Publishers, pp.1-71, 1986.

5) Roy, J. R. and Johansson, B. : On planning and forecasting the location of retail and service activity, Regional Science and Urban Economics Vol.14, pp.433-452, 1984.

6) 文 世一・小林潔司・吉川和広 : 商業地再開発の規模 と構成に関するモデル分析手法、土木学会論文集 第 401号/IV-10、pp.69-78、1989.

7) Anderson, S. P., de Palma, A. and Thisse, J. F. : Discrete Choice Theory of Product Differentiation, MIT Press, 1992.

8) Williams, H. C. W. L. : On the formation of travel demand models and economic evaluation measures of user benefit, Environment and Planning A, Vol. 9, pp.285-344, 1977.

\section{商業活動の立地均衡と社会的効率性}

文 世-

二通りの商業立地均衡を定式化し、立地分布の特性および社会的効率性を分析している。第 1 のモデルは、多数 の小規模小売業者が完全競争的に行動する状況を想定しており、第 2 のモデルでは、少数の大規模小売業者によ る塞占競争を想定している。これら二通りの立地均衡解を、パレート効率的な立地配分問題の解と比較すること によって、それらの社会的効率性について調べている。また、数值シミュレーションにより、立地パターンと、 主体間の経済厚生の分配について分析した。

Two types of retail location equilibria are formulated to analyze the effects of industrial organizations on spatial patterns and social efficiency. The first model supposes that all retailers are of small size and behave as price-takers, while the second model supposes the oligopoly by large scale retailers. I examined social efficiency of these two equilibrium solutions by comparing with Pareto-efficient allocation. I also analyzed the spatial patterns of retail location, and distribution of economic welfare among agents by means of numerical simulations. 